\title{
Milk fat in structure formation of dairy products: a review
}

\section{Olga Rybak}

\section{Ternopil National Technical University "Ivan Puliui", Ternopil, Ukraine}

\begin{tabular}{l} 
Keywords: \\
Milk \\
Fat \\
Structure \\
Butter \\
Ice cream \\
Cheese \\
\hline \\
Article history: \\
Received \\
14.05 .2016 \\
Received in revised \\
form 22.09 .2016 \\
Accepted \\
01.09 .2016 \\
\hline
\end{tabular}

\section{Corresponding author:}

Olga Rybak

E-mail: cmakota@ukr.net

\section{Abstract}

Introduction. This article primarily focuses on published information addressing how milk fat affects the structure of dairy products, published within the last 15 years. Texture is an important parameter in determining the consumer's acceptance of dairy foods as well as the sensory manifestation of product's structure. Therefore, establishment and maintenance of optimal structure are critical to high quality of product.

Material and methods. The structure formation of dairy products is an investigation object of this review article. Scientific articles as well as theses and monographs of dairy science have been analysed. Subjects of this research are properties of milk fat and wide variety of processes applied to the milk; the influence of milk fat on the structure of different dairy products.

Results and discussion. Milk fat occurs naturally in milk and cream, forming an oil-in-water emulsion. In the emulsion, milk fat is contained within milk fat globules, surrounded by the milk fat globule membrane. From a practical viewpoint, milk lipids are very important as they confer distinctive physical, chemical, textural and organoleptic properties on dairy products, such as cream, butter, ice cream, whipping cream and cheese.

Milk fat-based products, such as butter, are water-in-oil emulsions consisting of crystallized fat in a continuous phase, in which water droplets, milk fat globules, and partially damaged fat globules are dispersed. A microstructure dominated by numerous small crystals is shown to increase the hardness by up to $20 \%$ compared to a microstructure with few, but large crystals, a difference that from consumer perspective, would be noticed by different mouthfeel, brittleness, and spreadability.

Milk fat is essential for the formation of stable whipped cream and ice cream, which depend on the interaction between fat globules, air bubbles and plasma components (esp. proteins). During whipping and cooling fat globules partially coalesce in chains and clusters, and adsorb to and spread around the air bubbles. As the result, air bubbles are stabilized. Furthermore, fat is special importance for a solid ice cream structure to be formed during freezing and therefore for consistency, appearance, and melting resistance.

The presence of milk fat in cheese is necessary to develop the characteristic flavour and mouthfeel. Moreover, fat globules have an impact on texture by partially disrupting the casein fibrous matrix to soften the texture.

Conclusion. Milk fat is valued for its pleasant flavour but its properties often need to be modified to make it more suitable for food applications, which in turn can have a marked effect on the structure formation of dairy products, such as butter, whipping cream, ice cream and cheese. 


\section{Introduction}

The presence of fat globules in milk was first reported by Van Leeuwenhoek in 1674, after microscopic analysis of milk placed in a fine capillary tube. Since then, the physical and colloidal properties of milk fat globules and their size distribution have been the subject of considerable study.

Bovine milk typically contains $>10^{10}$ fat globules per $\mathrm{mL}$. Milk fat is present predominantly in spherical droplets ranging from about 0.2 to $15.0 \mu \mathrm{m}$ in diameter, with the bulk of the fat being in globules 1.0 to $8.0 \mu \mathrm{m}$ diameter [1]. The fat globules in milk are stabilized by an adsorbed layer of protein and phospholipid called the 'milk fat globule membrane' (MFGM), which is distinct from the aqueous phase protein. The MFGM, acting as an emulsifier, stabilizes the fat globules in the emulsion by lowering the surface tension $[2,3,4]$. In addition, it protects the fat from chemical reactions such as hydrolysis and oxidation [5]. The average composition of the MFGM has been estimated to be about $48 \%$ protein, $33 \%$ phospholipid, and $11 \%$ water, with the remainder made up of other minor lipid components [6,7]. The phospholipid fraction of the membrane is composed of lecithin, phosphatidyl ethanolamine, phosphatidyl serine, phosphatidyl inositide, plasmalogens and sphingomyelin. Phospholipids are important food emulsifiers in their own right $[8,9]$. Milk fat, on the other hand, contains a wide range of triglycerides, with a broad thermal range of melting points ranging from -50 to $80^{\circ} \mathrm{C}$.

\section{Material and methods}

The structure formation of dairy products is an investigation object of this review article. Scientific articles as well as theses and monographs of dairy science have been analysed. Subjects of this research are properties of milk fat and wide variety of processes applied to the milk; the influence of milk fat on the structure of different dairy products.

Methodology of the investigation is based upon the use of the methods of analysis, comparison and synthesis.

\section{Results and discussion}

Whole milk or cream can be regarded as an emulsion of milk fat globules in milk plasma. The physico-chemical properties of the milk fat globules affect many properties of dairy products. The physico-chemical properties of the milk fat globules can be influenced through a wide variety of processes. These processes can be efficiently used to give products desired characteristics (e.g., in terms of storage stability or rheological properties) $[10,11,12]$.

The shelf-life of many dairy emulsions depends on rheological characteristics of the emulsion's phases. For example, the rate of creaming of milk depends on the viscosity of milk plasma [13]. The content of lactose or the whey proteins in milk influence the viscosity of milk only little; fat content has a major influence, although by far the greatest influence is that of the casein content $[8,14]$. If fat globules are present as separate particles, the fat content is less $40 \%$ and the milk fat completely molten, milk and cream behave as Newtonian fluids at intermediate and high shear rates. At a temperature below $40{ }^{\circ} \mathrm{C}$, milk does not behave as a Newtonion fluid. The deviation from Newtonian flow becomes larger as the temperature decreases. Viscosity of milk decreases with increasing shear rate at a temperature below $40{ }^{\circ} \mathrm{C}$, which may be due to disruption of clusters of milk fat globules, which were formed as a result of cold agglutination. 
Heating. When fat globules are heated in the absence of whey proteins, high molecular weight complexes form between butyrophilin and Xanthine oxidoreductase in less than $10 \mathrm{~min}$ at a temperature as low as $60{ }^{\circ} \mathrm{C}$ [7]. In the presence of whey proteins, large amounts of $\beta$ lactoglobulin and $\alpha$-lactalbumin associate with the MFGM [15]. Direct evidence of heat-induced covalent disulfide interactions between whey proteins and MFGM proteins can be obtained by electrophoresis and isoelectric focusing of the heated MFGM [7, 16, 17]. The heat-induced formation of protein complexes on the surface of the MFGM may include denaturation of the individual proteins with the formation of aggregates containing MFGM proteins alone or MFGM proteins with whey proteins.

Mechanical treatments such as agitation, pumping and high shear can cause changes in the composition of the MFGM, as well as changes in the size of the fat globules. Homogenization is often employed to reduce the size of the fat globules, improve stability and delay creaming [18, 19]. During homogenization, the interfacial area increases significantly. Rearrangement of the original MFGM material occurs and considerably more protein is necessary to cover the newly formed interface. For this reason, casein micelles are adsorbed on the milk fat globules. This effect explains the observation that the fat globules in homogenized milk have a much higher protein load than untreated fat globules. Homogenization and heating are unit operations that are usually combined during milk processing $[8,10,20,21]$.

The formation of complexes between skim milk-derived proteins and MFGM proteins is of significance in milk processing [22]. When raw cream is homogenized without being subjected immediately to high-temperature pasteurization, indigenous milk lipoprotein lipase penetrates the secondary membrane of fat globules (which has higher interfacial tension than native membrane) and hydrolyzes triglycerides to free fatty acids within a few minutes, resulting in intense rancidity $[19,20]$.

Fat Destabilization. While homogenization is the principal method for achieving stabilization of the fat emulsion in milk, fat destabilization is necessary for structure formation in butter, whipping cream and ice cream $[10,13]$. Fat destabilization refers to the process of clustering and clumping (partial coalescence) of the fat globules, which leads to the development of a continuous internal fat network or matrix structure in the product. Fat destabilization (sometimes "fat agglomeration") is a general term that describes the summation of several different phenomena [8, 13, 23]. These include [9]:

Coalescence: an irreversible increase in the size of fat globules and a loss of identity of the coalescing globules;

Flocculation: a reversible (with minor energy input) agglomeration/clustering of fat globules with no loss of identity of the globules. The fat globules that flocculate, they can be easily redispersed if they are held together by weak forces, or they might be harder to redisperse to they share part of their interfacial layers;

Partial coalescence: an irreversible agglomeration/clustering of fat globules, held together by a combination of fat crystals and liquid fat, and a retention of identity of individual globules as long as the crystal structure is maintained (i.e., temperature dependent, once the crystals melt, the cluster coalesces). They usually come together in a shear field, as in whipping, and it is envisioned that the crystals at the surface of the droplets are responsible for causing colliding globules to stick together, while the liquid fat partially flows between they and acts as the "cement". Partial coalescence dominates structure formation in whipped, aerated dairy emulsions, crystals within the emulsion droplets are responsible for its occurrence.

The crystallization behavior of milk fat is extremely important to the processing and texture of dairy foods. For example, the crystal network structure of butter depends on its composition and the crystallization behavior of the milk fat present. In turn, these properties 
determine the end use applications, spreadability, mouthfeel, appearance and even the taste of butter [10].

Milk fat is composed of literally hundreds of unique and varied triacylglycerol (TAG) species. This results in milk fat having complicated crystallization, melting, and rheological behaviour $[24,25,26]$.

Crystallization refers to the change from a liquid to a solid state and is an exothermic process. It involves nucleation, crystal growth and crystal rearrangements. When a fat is cooled to a temperature below its melting point, the molecules are "supercooled". Supercooling is equivalent to supersaturation and is the thermodynamic driving force for crystallization to occur. In this nonequilibrium state, molecules begin to aggregate into tiny clusters (i.e., embryos), which continuously form and dissolve until some critical size is reached. At this point, the cluster is referred to as a nucleus [9,27].

The fat crystal network is held together by crystal-crystal interactions, characterized by strong irreversible (primary) bonds and weak reversible van der Waals (secondary) bonds $[8,23]$. The irreversible are formed upon crystal growth, as the crystals get mechanically interlinked. Fat crystal networks develop from initial nucleation sites, which grow into crystals as more TAGs crystallize (there may be further nucleation during growth) [25]. Growing crystals become primary particles, or microstructural elements (collection of primary crystallites or single crystals), of approximately uniform size $(<5 \mu \mathrm{m})$. These microstructural elements then aggregate into clusters, or microstructures $(>100 \mu \mathrm{m})$. They constitute the largest structural building block of the fat crystal network. The liquid phase (oil) of the network is interspersed between the microstructural elements and microstructure $[10,28]$.

The properties of the fat crystal network depend on the interactions between the crystals. Crystal size, shape, and polymorphic structure, as determined by processing conditions and chemical composition, affect the crystal-crystal interactions. [24, 25, 29, 30].

So, milk fat can be affected greatly by various processes (e.g., heat treatment, cooling or homogenization), which has significant influence on its application in a manufacturing of different dairy products.

Butter is water-in-oil emulsions consisting of crystallized fat in a continuous phase, in which water droplets $(2.3-10.6 \mu \mathrm{m})$ [31, 32], milk fat globules $(2.5 \mu \mathrm{m})$ [33], and partially damaged fat globules are dispersed. It contains $80 \%$ of fat, which is partly crystallized. Figure 1 shows a schematic representation of the physical changes involved.

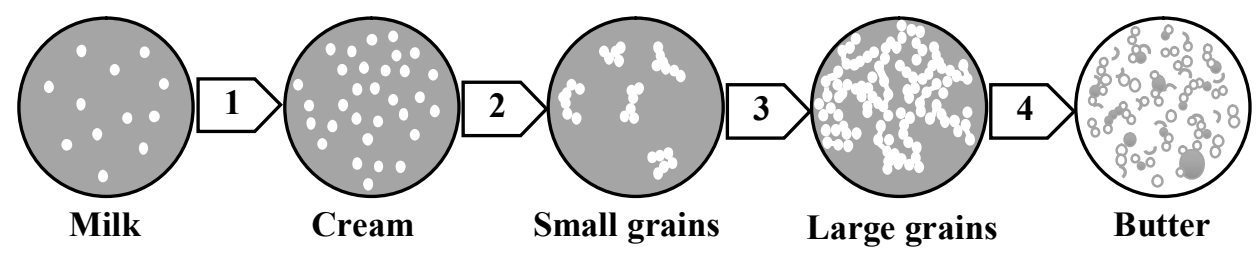

Figure 1. Stages in the formation of butter: grey represents the aqueous phase; white represents fat (1 - separation, 2 - churning, 3 - churning and draining, 4 - working) [34]

In most cases, the churning is achieved by beating in of air. Rapid beating in of air in milk or cream causes a new airwater interface to be continually formed, and fat spread over the interface $[8,10]$. If the fat is fully liquid, the subsequent breaking up of air bubbles 
covered with fat causes disruption of the fat. If the globules also contain solid fat, they become attached to the air bubbles. As the air surface area diminishes (because air bubbles coalesce), the attached fat globules are driven nearer to each other. The liquid fat spread over the air bubble surface, readily causes the globules to form granules [34] (Figure 2).

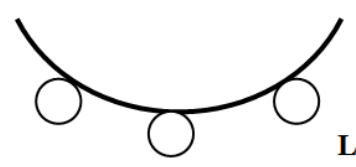

Liquid fat
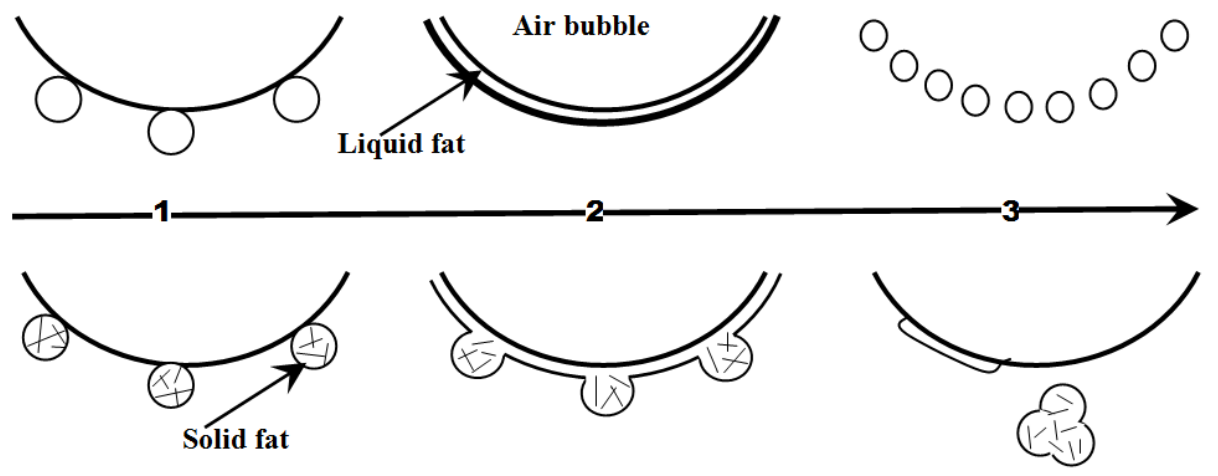

Figure 2. Schematic representation of the interactions between fat globules and air bubbles during churning

Further aggregation of granules yields butter grains, in which a phase inversion has apparently taken place. However, the grains still contain fat globules and moisture droplets. Concentrating and then working the grains removes excessive moisture and reduces the moisture droplets in size. In this way, butter is obtained. Figure 3 illustrate the microstructure of butter.

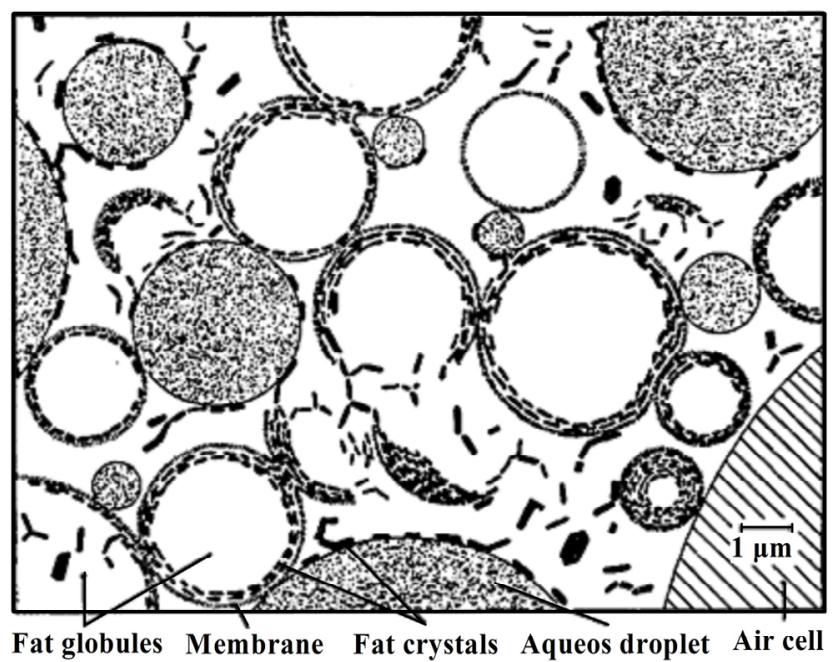

Figure 3. Schematic presentation of butter microstructure at room temperature: liquid fat is white; membrane thickness is greatly (about ten times) exaggerated [34] 
Several factors affect both the rate and the efficiency of the churning process. The type and filling level of the churn, as well as the turning speed of the churn, naturally influence the churning process $[10,20]$.

The proportion of solid fat is crucial. If the fat is fully liquid, a kind of homogenizing rather than churning occurs. Also, if the globules contain very little solid fat, then the cream does not churn. The clumps formed are soon pulled to pieces. But for the rest, the higher the proportion of solid fat, the slower the churning and the lower the fat content in the buttermilk. If the fat globules contain relatively little liquid fat, they can still be attached to the air bubbles, and the first stages of the churning, in which flotation predominates, do occur. The temperature therefore has a considerable effect on the churning. If the precooling is not sufficiently deep, undercooled (that is, liquid) fat globules will still be present, and the fat content of the buttermilk will substantially increase.

A partial phase inversion does occur during the churning; a continuous fat phase has developed in the butter granules (Figure 1). Nevertheless, in the whole mass of butter grains, the aqueous phase is still continuous. The working accomplishes a further phase inversion. In this stage, excessive moisture is squeezed out and the remaining moisture droplets are disrupted into smaller ones. This does not concern the very small moisture droplets that are left between individual clumped fat globules; these are too small (on average about $2 \mu \mathrm{m}$ ) to be disrupted by the working.

Increasing the working speed causes the droplets to become smaller, the butter becomes 'dry'. Likewise, moisture can be incorporated into the butter. During working at a very slow speed, larger droplets emerge again, especially at low temperature; the butter becomes 'wet' i.e., visible droplets appear. In that way, excessive moisture can be worked out of the butter. The butter can also readily become 'wet' during repackaging in retail packages.

A striking and important difference with, for example, margarine is the presence of several intact fat globules. Their number depends on the method of manufacture, and it decreases strongly with intensive working. Note that most crystals in the fat globules are tangentially arranged. The continuous phase is liquid fat. Sometimes a continuous aqueous phase persists, especially in insufficiently worked butter. This aqueous phase partly passes through the surface layers of the fat globules. The fact that displacement of water through butter can occur generally has another cause: approximately $0.2 \%(\mathrm{v} / \mathrm{v})$ water can dissolve in liquid fat, which implies that water can diffuse through the continuous oil phase. The ratio between liquid and solid fat is of utmost importance for the rheological properties of butter and spreads. Without solid fat, a milk fat-based product is fully liquid. Without liquid fat, it would appear hard and brittle [35, 36, 37].

The rheological properties of fat-based products are influenced by the fat crystal structure, solidification, and transformation behaviour [38]. The fat crystals consist of triglyceride molecules, forming nanoscale structured elements (150- to 350-nm long and 10 - to $60-\mathrm{nm}$ thick) assembled into network of fat crystals $(20$ to $100 \mu \mathrm{m})$ [39]. A microstructure dominated by numerous small crystals is shown to increase the hardness by up to $20 \%$ compared to a microstructure with few, but large crystals, a difference that from consumer perspective, would be noticed by different mouthfeel, brittleness, and spreadability [40]. For milk fat, the broad range of triglycerides results in different polymorphic forms due to varying chain length and degree of saturation. The term polymorphism describes the type of lateral packing of the aliphatic triglyceride chains [38]. The lateral packing is influenced by factors such as cooling rate, agitation temperature, and the mechanical treatment $[11,14,18,41]$.

A significant part of the crystalline fat may be inside the fat globules because during churning liquid fat is extruded from the globules, mainly by spreading over the air bubbles. However, there are also crystals outside the globules, and these aggregate to a continuous 
network and may grow together to form a solid structure, which is mainly responsible for the firmness of butter. The crystals inside the globules do not participate in this network and, therefore, they hardly make the butter firmer.

The crystals outside the fat globules thus make up a continuous network, in which part of the water droplets and damaged fat globules may participate. This network retains the liquid fat as a sponge. When the temperature increases, many crystals melt and the network becomes less dense and coarser.

The structural stability and rheological behavior of butter and milk fat-based products is primarily determined by stabilization by the fat crystal network [42-44]. The fat crystal network is strengthened by formation of more and stronger crystal-crystal interactions due to mechanically interlinked fat crystals as occurring during crystal growth. Initially, the crystals are kept together by van der Waals forces, but they soon become much more strongly bonded to each other due to sintering. Part of the fat is in fat globules, and crystals in these globules do not participate in the fat crystal network. If this is a substantial portion of the solid fat, the firmness of the butter will be decreased. Very intensive or prolonged working can reduce the quantity of globular fat.

Microstructural changes of fat crystals during storage are, however, the biggest challenge to maintain the initially induced rheological differences in milk fat-based products. During subsequent storage, the continuously super-cooled fat will eventually crystallize and thereby strengthen the fat crystal network independently of processing conditions [45].

Whipping cream ranks among premium food products and is consumed for its pure flavor. The whipping of pasteurized cream containing more than $30 \%$ fat is possible only after adequate cooling since the transformation of the original $\mathrm{o} / \mathrm{w}$ emulsion into a stable foam requires that part of the fat is solid. The initial stage of whipping involves stabilization of the trapped air bubbles by a temporary interfacial film of soluble whey proteins and $\beta$-casein. On mechanical treatment, fat globules increasingly loose at least segments of their natural membrane, thereby exposing strongly hydrophobic surface areas of pure fat. Subsequently, these partly destabilized fat globules adsorb at the air/serum interface of the air bubbles (figure 4). The leakage of liquid fat from mechanically stressed and deformed fat globules supports globule agglomeration and partial coalescence. These agglomerates also interact with the air bubbles and may form bridges between them $[9,13$, 20]. 


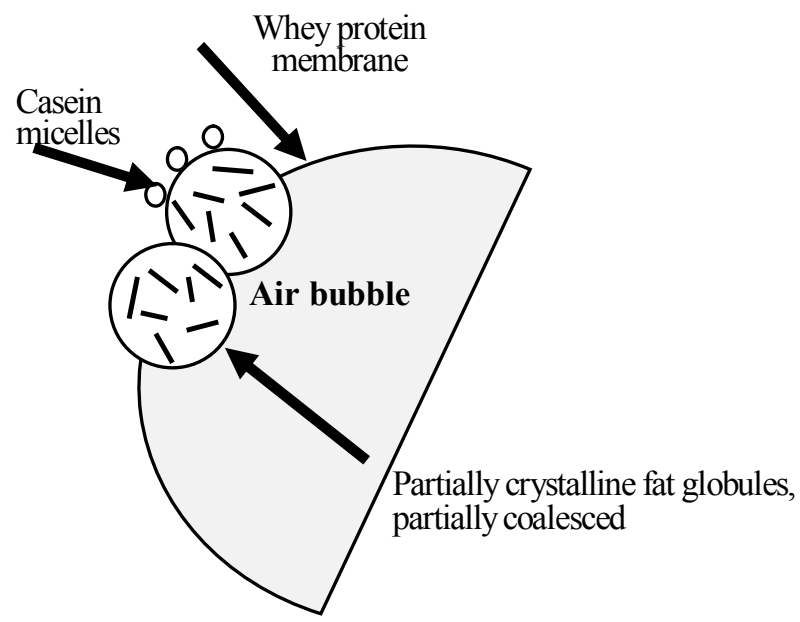

Figure 4. Schematic representation of the air bubble stabilization in whipping cream

As the fat partially coalesces, it causes one fat-stabilized air bubble to be linked to the next, and so on. The whipped cream soon starts to become stiff and dry appearing and takes on a smooth texture. This results from the formation of this partially coalesced fat structure stabilizing the air bubbles. The water, lactose and proteins are trapped in the spaces around the fat-stabilized air bubbles. The crystalline fat content is essential (hence, whipping of cream is very temperature dependent) so that the fat globules partially coalesce into a 3dimensional structure rather than fully coalesce into larger and larger globules that are not capable of structure-building. This is caused by the crystals within the globules that cause them to stick together into chains and clusters, but still retain the individual identity of the globules [10, 34].

In homogenized cream, partial coalescence is too slow, because the fat globules are too small and their proteinaceous surface layers provide good stability. However, homogenization at low pressure (1 to $4 \mathrm{MPa}$ ), gives rise to small homogenization clusters and such a cream can be whipped $[8,13]$. Another measure to enhance whippability is the addition of a suitable smallmolecule surfactant (usually called emulsifier) that displaces (part of) the protein from the globule surface. This enhances the susceptibility of the globules to partial coalescence and markedly affects whipping properties.

The structure of whipped cream is very similar to the fat and air structure that exists in ice cream.

The fat component of frozen dairy dessert mixes increases the richness of flavor, is a good carrier and synergist for added flavor compounds, produces a characteristic smooth texture by lubricating the palate, helps to give structure through the process of partial coalescence and foam stabilization and aids in producing desirable melting properties [46]. The fat content is an indicator of the perceived quality and/or value of ice cream. A high fat content leads to a dry, almost grainy texture, a low fat content to a smooth, homogeneous, somewhat slimy texture $[47,48]$.

To describe the role of fat in the structure thoroughly, it is necessary to begin with the formation of the emulsion at the time of homogenization and the role of the ingredients present at the time of homogenization, with particular reference to the fat, proteins and emulsifiers [49]. The milk fat exists in tiny globules that have been formed by the homogenization. The creation of a large population of small, discrete droplets is a 
prerequisite for the development of structure during dynamic freezing, utilizing these droplets. Thus, homogenization conditions can have a large impact on ice cream structure [50-53]. There are many proteins that act as emulsifiers and give the fat emulsion its needed stability. The emulsifiers are added to ice cream to actually reduce the stability of this fat emulsion by replacing proteins on the fat surface [54, 55] (figure 5), leading to a thinner membrane more prone to coalescence during whipping $[13,56]$.

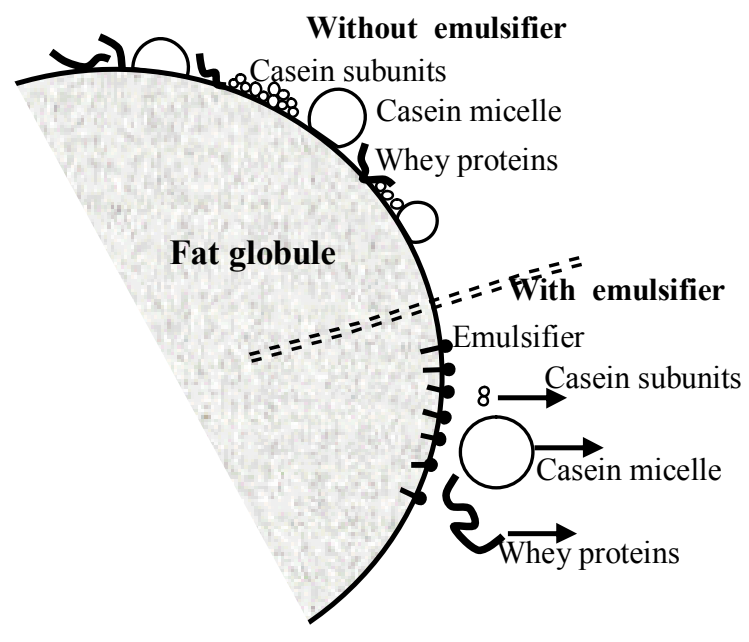

Figure5. Schematic representation of the interactions between fat globules and emulsifier in ice cream

Fat crystallization occurs during ageing, creating a highly intricate structure of needle-like crystals within the globule. A partially crystalline fat droplet is necessary for optimal fat structure formation to occur during freezing [57, 58]. When the mix is subjected to the whipping action of the freezer, the fat emulsion begins to partially break down and the fat globules begin to flocculate or destabilize. The air bubbles which are being incorporated into the mix are stabilized by this partially coalesced fat [59]. If emulsifiers were not added, the fat globules would have so much ability to resist this coalescing, due to the proteins being adsorbed to the fat globule, that the air bubbles would not be properly stabilized and the ice cream would not have the same smooth texture (due to this fat structure) that it has.

The clumped fat globules, together with the air cells to which they are attached, form a continuous network throughout the liquid (Figure 6). The clusters of fat globules formed during the process of partial coalescence are responsible for adsorbing to, and stabilizing, the air cells $[56,60]$ and creating a semi-continuous network or matrix of fat throughout the product that crosses the lamellae between the air cells $[50,61]$. Hence, a liner distribution of air bubbles, resulting in thinner lamellae, also helps to produce optimal shape retention during extrusion and melting [62]. Optimal formation of fat structure and air bubble size may also help to slow down ice recrystallization [60]. 


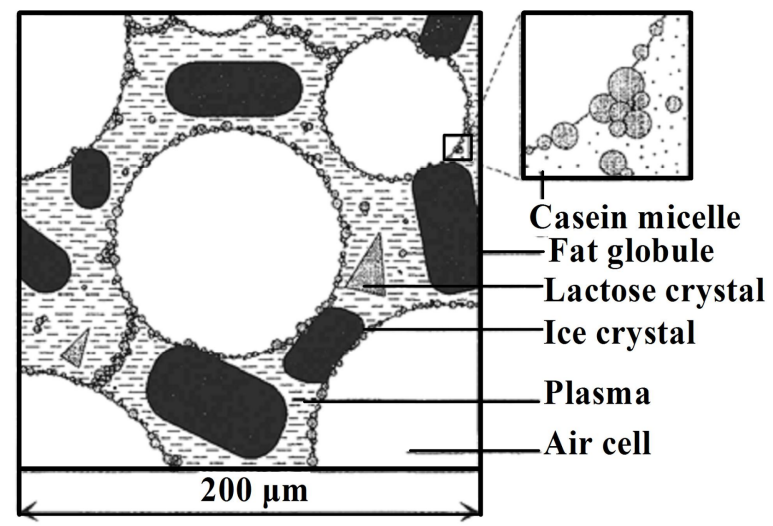

Figure 6. Schematic presentation of the microstructure of ice cream [34]

The network of clumped fat globules is formed during freezing. Although the air bubbles become almost completely covered with fat globules, flotation churning presumably does not occur, because too little liquid fat is available to spread over the air bubbles. In all likelihood, clumping is predominantly caused by mechanical forces, i.e., the fat globules are pushed together during beating because of the presence of ice crystals and are damaged by them. The lower temperature occurs more ice and faster clumping.

If unhomogenized cream would be taken, all the fat globules together would just suffice to cover air cells. But natural milk fat globules clump rapidly, and the aggregates formed are not nearly sufficient to fully 'encapsulate' such air cells. This implies that the cells would be unstable during and after freezing and large air bubbles develop, causing a coarse texture. The fat globules become much smaller in size by homogenization of the cream, and then they can cover a much larger air cell surface even after clumping [51,52]. The homogenized fat globules will, however, hardly clump, so the desired network of clumped fat globules does not form. However, these globules increasingly tend to clump if a suitable, small-molecule surfactant (emulsifier) is added. This is due to the emulsifier displacing part of the protein from the surface layers, which decreases the stability of the fat globules to partial coalescence; the globules also become more readily attached to the air bubbles [60].

Fat is a major component in most cheese types. The presence of fat in cheese is necessary, in most cases, to develop the characteristic flavour profile and mouth-feel. Fat globules also have an impact on texture by partially disrupting the casein fibrous matrix to soften the texture [63]. The level of fat influences several aspects of cheese, including composition, biochemistry, microstructure, yield, rheological and textural properties [64, 65]. Moreover, for a given fat content, the type of fat (melting point) and the state of the fat (non-globular, free fat, homogenized, globule size distribution, solid-to-liquid ratio) has a major impact on the rheology, flavor and cooking properties of cheese $[66,67]$.

There is some debate about whether fat globules participate directly in cheese microstructure by binding to the casein matrix, or act as inert filler material by partially disrupting the casein matrix. Undoubtedly, both mechanisms occur to some extent, as large fat globules are more likely to disrupt the matrix compared to the smaller globules occluded within the protein void spaces. Large fat globules are more likely to be distorted, and 
perhaps exist as free fat trapped within the protein void spaces compared to small fat globules [68, 69].

Cheese is essentially a concentrated protein gel, which occludes fat, moisture, and other materials. The gelation of milk is characterized by aggregation of the rennet-altered casein micelles into interconnected clusters and forming a network in which fat globules are interspersed as loose inclusions [70]. As the protein matrix contracts and adjoining curd particles mat through their fat-depleted surface layers, these fat-depleted areas become part of the internal structure of the cheese. The enmeshed fat globules occupy the spaces between the protein strands and may be considered to impede physically the aggregation of the para-casein matrix, to a degree dependent on their volume fraction and size distribution [63]. Consequently, a higher fat level leads to slower syneresis during manufacture [71], and an increase in the level of MNFS in the cheese. The increase in MNFS has a major impact on cheese yield and quality.

Some clumping and/or coalescence of fat globules generally occur in most cheese varieties [10]. In contrast to Cheddar and Mozzarella, relatively little clumping and coalescence of fat globules is evident in other cheese types such as Cheshire, Gouda or Meshanger cheese. The relatively high degree of fat globule coalescence in Cheddar and Mozzarella is probably due to the relatively large displacement of neighboring layers of protein matrix, between which fat globules and fat globule clusters are sandwiched during the cheddaring and/or kneading/ stretching stages of manufacture. Such displacement can be expected to "stretch" the fat globules and, consequently, shear and disrupt their membranes $[20,71]$.

At the temperatures used in the manufacture of cheese $\left(\sim 30-55^{\circ} \mathrm{C}\right)$ much, or all, of milk fat is liquid and can therefore flow and aggregate, leading to coalescence on the application of stress. A significant portion of the fat $(\sim 20-30 \%$ total $)$ may be liquid at the ripening temperatures $\left(\sim 4-7^{\circ} \mathrm{C}\right)$, and will aggregate, leading to coalescence $[8,72]$.

Compared to natural cheese, there is less clumping or coalescence of fat globules in Pasteurized Processed Cheese Products and Analogue Cheese Products. Consequently, the mean fat globule size tends to be generally smaller, although it varies depending on the type and level of emulsifying salt, types and levels of milk protein added, processing time. Generally, for most emulsifying salts, the fat globule size decreases as the processing time at a high temperature increases [72-75].

Increasing the fat content results in a reduction in the volume fraction and continuity of the casein matrix, which becomes more interrupted by fat globules [20]. Concomitantly, the fat globules become more numerous and varied in size and shape, and the degree of clumping and coalescence of the fat globules increase. The increased degree of fat globule aggregation is expected because the number of encounters of the fat globules within a given volume of the casein matrix increases as the enveloping protein matrix contracts during manufacture and as the curd particles undergo deformation during the various stages of cheese making [10, 62, 71]. Conversely, as the fat content of cheese is reduced there are longer stretches of uninterrupted casein matrix and the fat globules become more uniformly dispersed and less clumping is evident.

In Camembert cheese fat globules can both interact with the surrounding protein matrix or serve as protein matrix breakers. Larger fat globules in Camembert cheese tend to be more aggregated and are surrounded by thick protein strands, whereas smaller globules are enveloped by thinner protein strands [76]. The higher total surface area of smaller fat globules may allow greater water binding and moisture retention in the cheese. In addition, small globules are associated with small voids in the protein matrix that more effectively trap water, resulting in a higher-moisture cheese. 


\section{Conclusions}

Milk fat can be influenced through a wide variety of processes applied to the milk, particularly homogenization, cooling, heating, which has significant implications for the properties of milk fat globules. These processes are efficiently used to give products desired characteristics and milk fat can have different effect on the structure formation of dairy products. The structural stability and rheological behaviour of butter and milk fat-based products is primarily determined by stabilization by the fat crystal network. Stronger crystal-crystal interactions are very important for good quality of butter. The formation of stable structure of whipped products, such as ice cream and whipping cream, depends on the interaction between fat globules, air bubbles and proteins. Partly destabilized fat globules adsorb at the air/serum interface of the air bubbles. As the fat partially coalesces, it causes one fat-stabilized air bubble to be linked to the next, and foam structure are formed. In cheese's structure formation milk fat is an accessory structure element.

A more detailed understanding is needed of how the presence of milk fat globules is related to the rheological behaviour and structure formation of dairy products. For further studies, it would be relevant to relate the rheological differences observed as a function of thermal and mechanical treatments, and the milk composition of different mammals to the sensory quality of milk-based products. A detailed study addressing this statement would provide valuable knowledge at the industrial level. However, several steps are needed to link the existing knowledge to industrial applications of new products with a high functional value and nutritional quality.

\section{References}

1. Michalski M.C., Ollivon M., Briard V., Leconte N., Lopez C. (2004), Native fat globules of different sizes selected from raw milk: thermal and structural behaviour, Chemistry and Physics of Lipids, 132, pp. 247-261.

2. Corredig M., Dalgleish D.G. (1998), Characterization of the interface of an oil-inwater emulsion stabilized by milk fat globule membrane material, Journal of Dairy Research, 65, pp. 465-477.

3. Evers J.M. (2004), The milk fat globule membrane - compositional and structural changes post secretion by the mammary secretory cell, International Dairy Journal, 14, pp. 661-674.

4. Lee S.J., Sherbon J.W. (2002), Chemical changes in bovine milk fat globule membrane caused by heat treatment and homogenization of whole milk, Journal of Dairy Research, 69, pp. 555-567.

5. Lopez C. (2005), Focus on the supramolecular structure of milk fat in dairy products, Reproduction Nutrition Development, 45, pp. 497-511.

6. Mather I.H. (2000), A review and proposed nomenclature for major proteins of the milk-fat globule membrane, Journal of Dairy Science, 83, pp. 203-247.

7. Ye A., Singh H., Taylor M.W., Anema S. (2002), Characterization of protein components of natural and heat-treated milk fat globule membranes, International Dairy Journal, 12, pp. 393-402.

8. Roginski H., Fuquay J.W., Fox P.F. (2011), Encyclopedia of Dairy Science, Elsevier Ltd: Academic Press, London.

9. Belitz H.D., Grosch W., Schieberle P. (2009), Food chemistry: 4th ed. Leipzig, Springer-Verlag.

10. Tamime A. Y. (2007), Structure of dairy product, Blackwell Publishing Ltd. 
11. Herrera M.L., Hartel R.W. (2000), Effect of processing conditions on crystallization kinetics of a milk fat model system, Journal of the American Oil Chemists' Society, 77, pp. 1177-1187.

12. Hillbrick G., Augustin M.A. (2002), Milkfat characteristics and functionality: Opportunities for improvement, Australian Journal of Dairy Technology, 57, pp. 45-51.

13. Mc Clements D.J. (1999), Food Emulsions, Principles, Practice and Techniques, CRC Press, Boca Raton.

14. Herrera M.L., Hartel, R.W. (2000). Effect of processing conditions on physical properties of a milk fat model system: Rheology, Journal of the American Oil Chemists' Society, 77, pp. 1189-1196.

15. Ye A., Singh H., Oldfield D.J., Anema S. (2004), Kinetics of heat-induced association of $\beta$-lactoglobulin and $\alpha$-lactalbumin with milk fat globule membrane in whole milk, International Dairy Journal, 14, pp. 389-398.

16. Kim H.-H.Y., Jimenez-Flores R. (1995), Heat-induced interactions between the proteins of milk fat globule membrane and skim milk, Journal of Dairy Science,78, pp. 24-35.

17. Corredig M., Dalgleish D.G. (1996), Effect of different heat treatments on the strong binding interactions between whey proteins and milk fat globules in whole milk, Journal of Dairy Research, 63, pp. 441-449.

18. Herrera M.L., Hartel R.W. (2000). Effect of processing conditions on physical properties of a milk fat model system: microstructure, Journal of the American Oil Chemists' Society, 77, pp. 1197-1205.

19. Gunstone F.D., Harwood J.L., Dijkstra A.J. (2007), The lipid handbook: 3rd ed. Boca Raton, CRC Press.

20. Fox P. F., McSweeney P. L. H. (2006), Advanced Dairy Chemistry: Volume 2 Lipids, Springer, New Yerk.

21. Sharma S.K., Dalgleish D.G. (1994), Effect of heat treatments on the incorporation of milk serum proteins into the fat globule membrane of homogenized milk, Journal of Dairy Research, 61, pp. 375-384.

22. Wright A., Scanlon M.G., Hartel R.W., Marangoni A.G. (2001). Rheological properties of milkfat and butter, Journal of Food Science, 66, pp. 1056-71.

23. P. F. Fox et al. (2015), Dairy Chemistry and Biochemistry, Springer International Publishing, Switzerland

24. Shi Y., Smith C., Hartel R. (2001), Compositional effects on milk fat crystallization, Journal of Dairy Science, 84, pp. 2392-2401.

25. Van Aken, G., Visser, K. (2000), Firmness and crystallization of milk fat in relation to processing conditions, Journal of Dairy Science, 83, pp. 1919-1932.

26. Vanhoutte, B., Dewettinch, K., Vanlergerghe, B. (2003), Monitoring milk fat fractionation: filtration properties and crystallization kinetics, Journal of the American Oil Chemists' Society, 80, pp. 213-218.

27. Rønholt S., Mortensen K., Knudsen J.C. (2013). The Effective Factors on the Structure of Butter and Other Milk Fat-Based Products, Comprehensive Reviews in Food Science and Food Safety, 12, pp. 468-482.

28. Wiking L., De Graef V., Rasmussen M., Dewettinck K. (2009), Relations between crystallization mechanism and microstructure of milk fat, International Dairy Journal, 19, pp. 424-430.

29. Campos, R., Narine, S.S., Marangoni. A.G. (2002), Effect of cooling rate on the structure and mechanical properties of milk fat and lard, Food Research International, 35, pp. 971-982.

30. Wright, A.J., Hartel, R.W., Narine, S.S., Marangoni, A.G. (2000), The effect of minor components on milk fat crystallization, Journal of the American Oil Chemists' Society, 77, pp. 463-475. 
31. van Dalen G. (2002), Determination of the water droplet size distribution of fat spreads using confocal laser scanning microscopy, Journal of Microscopy, 208, pp. $116-33$.

32. van Lent K., Vanlerberghe B., van Oostveldt P., Thas O., van der Meeren P. (2008), Determination of water droplet size distribution in butter: pulsed field gradient NMR in comparison with confocal laser scanning microscopy, International Dairy Journal, 18 , pp.12-22.

33. Rønholt S, Kirkensgaard J.J.K., Pedersen T.B., Mortensen K., Knudsen J.C. (2012), Polymorphism, microstructure and rheology of butter. Effects of cream heat treatment, Food Chemistry, 135, pp. 1730-1739.

34. Walstra P., Wouters J.T.M., Geurts T.J. (2005), Dairy science and technology: 2nd ed., CRC Press.

35. Kamleh R., Fanni J., Mayda E.E. (2010), Composition and rheological properties of butter produced in Bekaa Valley (Libanon), Journal of Food, Agriculture and Environment, 8, pp.186-189.

36. Kaufmann N., Andersen U., Wiking L. (2012), The effect of cooling rate and rapeseed oil addition on the melting behavior, texture and microstructure of anhydrous milk fat, International Dairy Journal, 25, pp. 73-79.

37. Marangoni A.G., Acevedo N., Maleky F., Co E., Peyronel F., Mazzanti G., Quinn B., Pink D. (2012), Structure and functionality of edible fats, Soft Matter, 8, pp. 12751300 .

38. Mazzanti G., Guthrie S.E., Sirota E.B., Marangoni A.G., Idziak SH.J. (2004), Effect of minor components and temperature profiles on polymorphism in milk fat, Crystal Growth and Design, 4, pp. 1303-1309.

39. Acevedo N., Marangoni A.G. (2010), Toward nanoscale engineering of triacylglycerol crystal networks, Crystal Growth and Design, 10 (8), pp 3334-3339.

40. Fedotova Y., Lencki R. (2010), The effect of phospholipids on butter physical and sensory properties, Journal of the American Oil Chemists' Society, 87, pp. 75-82.

41. Marangoni A.G., Ollivon M. (2007), Fractal character of triglyceride spherulites is a consequence of nucleation kinetics, Chemical Physics Letters, 442, pp. 360-364.

42. Litwinenko J.W., Rojas A.M., Gerschenson L.N., Marangoni A.G. (2002), Relationship between crystallization behavior, microstructure and mechanical properties in palm oil-based shortening, Journal of the American Oil Chemists' Society, 79 (7), pp 647-654.

43. Rousseau D., Zilnik L., Khan R., Hodge S. (2003), Dispersed phase destabilization in table spreads. Journal of the American Oil Chemists' Society, 80 (10), pp 957-961.

44. Alexa R.I., Mounsey J.S., O'Kennedy B.T., Jacquier J.C. (2010). Effect of kappacarrageenan on rheological properties, microstructure, texture and oxidative stability of water-in-oil spreads, LWT-Food Science and Technology, 43(6), pp. 843-848.

45. Rønholt S., Kirkensgaard J.J.K., Mortensen K., Knudsen J.C. (2014), Effect of cream cooling rate and water content on butter microstructure during four weeks of storage. Food Hydrocolloid, 34, pp. 169-176.

46. Marshall, R.T., Goff, H.D., Hartel, R.W. (2003), Ice Cream, 6th edn, Kluwer Academic, Plenum.

47. Goff, H.D. (2002), Formation and stabilization of structure in ice cream and related products, Current Opinion in Colloid \& Interface Science, 7, pp. 432-437.

48. Hyvonen, L., Linna, M., Tuorila, H., Dijksterhuis, G. (2003), Perception of melting and flavor release of ice cream containing different types and contents of fat, Journal of Dairy Science, 86, pp. 1130-1138.

49. Sourdet, S., Relkin, P., Cesar, B. (2003) Effects of milk protein type and pre-heating on physical stability of whipped and frozen emulsions, Colloids Surfaces B, 31, pp.55-64.

50. Koxholt, M.M.R., Eisenmann, B., Hinrichs, J. (2001), Effect of the fat globule sizes on the meltdown of ice cream, Journal of Dairy Science, 84, pp.31-37. 
51. Ruger, P.R., Baer, R.J., Kasperson, K.M. (2002), Effect of double homogenization and whey protein concentrate on the texture of ice cream, Journal of Dairy Science, 85, pp. 1684-1692.

52. Hayes, M.G., Lefrancois, A.C., Waldron, D.S., Goff, H.D., Kelly, A.L. (2003), Influence of high pressure homogenisation on some characteristics of ice cream, Milchwissenschaft, 58, pp. 519-523.

53. Olsen, D.W., White, C.H., Watson, C.E. (2003). Properties of frozen dairy desserts processed by microfluidization of their mixes, Journal of Dairy Science, 86, pp. $1157-1162$.

54. Rybak O. (2013), Some aspects of the formation of emulsions and foams in food industry, Ukrainian Journal of Food Science, 1, pp. 40-48.

55. Goff, H.D., Spagnuolo, P. (2001), Effect of stabilizers on fat destabilization measurements in ice cream, Milchwissenschaft, 56, pp.450-453.

56. Zhang, Z., Goff, H.D. (2004), Protein distribution at air interfaces in dairy foams and ice cream as affected by casein dissociation and emulsifiers, International Dairy Journal,14, pp. 647-657.

57. Davies, E., Dickinson, E., Bee, R.D. (2001). Orthokinetic destabilization of emulsions by saturated and unsaturated monoglycerides, International Dairy Journal,11, pp. 827-836.

58. Relkin, P., Sourdet, S., Fosseux, P.-Y. (2003), Fat crystallization in complex food emulsions: effects of adsorbed milk proteins and of a whipping process, Journal of Thermal Analysis and Calorimetry, 71, pp.187-195.

59. Chang, Y.H., Hartel, R.W. (2002), Development of air cells in a batch ice cream freezer, Journal of Food Engineering, 55, pp. 71-78.

60. Barfod, N.M. (2001), The emulsifier effect, Dairy Industries International, 66(1), pp. 32-33.

61. Muse M.R., Hartel R.W. (2004), Ice cream structural elements that affect melting rate and hardness, Journal of Dairy Science, 87, pp.1-10.

62. Bolliger S., Kornbrust B., Goff H.D., Tharp B.W., Windhab E.J. (2000), Influence of emulsifiers on ice cream produced by conventional freezing and low temperature extrusion processing, International Dairy Journal,10, pp. 497-504.

63. Fox P.F., Guinee T.P., Cogan T.M., McSweeney P.L.H. (2000), Fundamentals of Cheese Science. Aspen Publishers, Inc., Gaithersburg, MD.

64. Gwartney E.A., Foegeding E.A., Larick D.K. (2002), The texture of commercial fullfat and reduced-fat cheese, Journal of Food Science, 67, pp. 812-816.

65. Michaelidou A.A., Katsiari M.C., Kondyli E., Voustinas L.P., Alichanidis E. (2003), Effect of a commercial adjunct culture on proteolysis in low-fat Feta-type cheese, International Dairy Journal, 13, pp. 179-189.

66. Nair, M.G., Mistry, V.V., Oommen, B.S. (2000). Yield and functionality of Cheddar cheese as influenced by homogenization of cream, International Dairy Journal, 10, pp. 647-657.

67. Guinee T.P., Auty M.A.E., Fenelon M.A. (2000), The effect of fat content on the rheology, microstructure and heat-induced functional characteristics of Cheddar cheese, International Dairy Journal, 10, 277-288.

68. Michalski M.C., Camier B., Briard V., Leconte N., Gassi J.Y., Goudedranche H., Michel F., Fauquant J. (2004), The size of native milk fat globules affects physicochemical and functional properties of Emmental cheese, Lait, 84, pp. 343-358.

69. Rowney M.K., Hickey M.W., Roupas P., Everett D.W. (2003), The effect of homogenization and milk fat fractions on the functionality of Mozzarella cheese, Journal of Dairy Science, 86, pp. 712-718.

70. Rybak O. (2014), The role of milk proteins in the structure formation of dairy products, Ukrainian Food Journal, 3(3), pp. 350-360. 
71. Fox P.F., McSweeney P.LH., Cogan T.M., Guinee T.P. (2004). Cheese Chemistry, Physics and Microbiology, Vol. 1, General Aspects: 3rd edn, Elsevier Academic Press, Amsterdam.

72. Tamime A. Y. (2011), Processed Cheese and Analogues, Wiley-Blackwell.

73. Kapoor, R., Metzger L.E. (2008) Process cheese: scientific and technological aspects: a review, Comprehensive Reviews in Food Science and Food Safety, 7, pp. 194-214.

74. Kapoor R., Metzger L.E., Biswas A.C., Muthukmmarappan, K. (2007), Effect of natural cheese characteristics on process cheese properties, Journal of Dairy Science, 90, pp. 1625-1634.

75. Lee W.J., Clark S., Swanson B.G. (2006), Low fat process cheese food containing ultrahigh pressure-treated whey protein, Journal of Food Processing and Preservation, 30, pp. 164-179.

76. Michalski M.C., Gassi J.Y., Famelart M.H., Leconte N., Camier B., Michel F., Briard V. (2003), The size of native milk fat globules affects physico-chemical and sensory properties of Camembert cheese, Lait, 83, pp. 131-143. 